TITLE:

\title{
Precipitation behavior of highly Sr- doped LaPO4 in phosphoric acid solutions
}

\section{AUTHOR(S):}

Hatada, Naoyuki; Nose, Yoshitaro; Kuramitsu, Akiko; Uda, Tetsuya

\section{CITATION:}

Hatada, Naoyuki ...[et al]. Precipitation behavior of highly Sr-doped LaPO4 in phosphoric acid solutions. Journal of Materials Chemistry 2011, 21(24): 8781-8786

\section{ISSUE DATE:}

2011

URL:

http://hdl.handle.net/2433/156799

\section{RIGHT:}

(C) Royal Society of Chemistry 2011.; この論文は出版社版でありません 。引用の際には出版社版をご確認ご利用ください。; This is not the published version. Please cite only the published version. 


\title{
Precipitation behavior of highly Sr-doped $\mathrm{LaPO}_{4}$ in phosphoric acid solutions
}

\author{
Naoyuki Hatada, ${ }^{* a}$ Yoshitaro Nose, ${ }^{a}$ Akiko Kuramitsu ${ }^{a}$ and Tetsuya Uda* ${ }^{a}$ \\ Received (in $X X X, X X X) X$ th $X X X X X X X X X 200 X$, Accepted $X$ th $X X X X X X X X X 200 X$ \\ ${ }_{5}$ First published on the web $X$ th $X X X X X X X X X 200 X$ \\ DOI: 10.1039/b000000x
}

The precipitation condition of $\mathrm{LaPO}_{4}$ in phosphoric acid solution was investigated under both atmospheric and humidified conditions. The crystal morphology, Sr doping level, $\mathrm{H}_{2} \mathrm{O}$ incorporation, and high temperature stability of Sr-doped $\mathrm{LaPO}_{4}$ precipitates were also analyzed.

10 Increasing $p \mathrm{H}_{2} \mathrm{O}$ from 0.01 to $1 \mathrm{~atm}$ extends the precipitation region of $\mathrm{LaPO}_{4}$ in phosphoric acid solutions toward higher temperatures by nearly $100{ }^{\circ} \mathrm{C}$. Under such conditions (e.g. $T=250^{\circ} \mathrm{C}$ and $p \mathrm{H}_{2} \mathrm{O}=1 \mathrm{~atm}$ ), it is possible to obtain aggregated crystals up to $200 \mu \mathrm{m}$. The $\mathrm{Sr}$ doping level in $\mathrm{LaPO}_{4}$ shows a strong dependence on the precipitation ratio of La, $X_{\mathrm{La}}$. The $\mathrm{Sr}$ doping level is higher in the low $X_{\mathrm{La}}$ region, reaching $20 \mathrm{~mol} \%$ at maximum. This value is one order of magnitude 15 higher than the previously reported solubilities. It was confirmed $\mathrm{H}_{2} \mathrm{O}$ is certainly incorporated in the bulk by Sr doping. The solubility of $\mathrm{Sr}$ in $\mathrm{LaPO}_{4}$ would be sufficiently high (at least $20.1 \%$ ) even at $600{ }^{\circ} \mathrm{C}$; however, it becomes considerably lower at $1200{ }^{\circ} \mathrm{C}$.

\section{Introduction}

In recent years, lanthanum orthophosphate $\left(\mathrm{LaPO}_{4}\right)$ has 20 received attention because of its potential application as a solid electrolyte in fuel cells. ${ }^{1-4}$ It exhibits protonic conductivity on the order of $10^{-4} \mathrm{~S} \mathrm{~cm}^{-1}$ at $700{ }^{\circ} \mathrm{C}$ when La is partially substituted with alkaline earth metals such as Sr. ${ }^{1,5}$ For practical use, however, further enhancement of the 25 conductivity is necessary.

Amezawa et al. reported that the conductivity of Sr-doped $\mathrm{LaPO}_{4}$ increased with increasing the dopant concentration. ${ }^{6}$ They also reported that the solubility of $\mathrm{Sr}$ in $\mathrm{LaPO}_{4}$, represented by the molar ratio $\mathrm{Sr} /(\mathrm{La}+\mathrm{Sr})$, was approximately 302 \%. ${ }^{7}$ With higher $\mathrm{Sr}$ mixing ratios, a secondary phase, $\mathrm{Sr}_{2} \mathrm{P}_{2} \mathrm{O}_{7}$, appeared and the conductivity decreased with increasing $\mathrm{Sr}$ concentration. Thus, the low solubility of $\mathrm{Sr}$ is an obstacle to enhancing the conductivity of $\mathrm{LaPO}_{4}$.

While the solubility research described above was 35 conducted with samples prepared by solid state reaction and sintered at $1200{ }^{\circ} \mathrm{C}$, ${ }^{7}$ there are several reports of different $\mathrm{Sr}$ doping levels with different synthesis temperatures. Tyholdt $e t$ al. reported the solubility of $\mathrm{Sr}$ in $\mathrm{LaPO}_{4}$ to be $\sim 1 \%$ with samples sintered at $1450{ }^{\circ} \mathrm{C} .{ }^{8}$ Gallini et al. prepared $5 \% \mathrm{Sr}$ 40 doped $\mathrm{LaPO}_{4}$ by combustion synthesis followed by calcination at $800{ }^{\circ} \mathrm{C}$. ${ }^{3}$ Schatzmann et al. synthesized Sr-doped $\mathrm{LaPO}_{4}$ by adding $\mathrm{La}\left(\mathrm{NO}_{3}\right)_{3} \cdot 6 \mathrm{H}_{2} \mathrm{O}$ and $\mathrm{Sr}\left(\mathrm{NO}_{3}\right)_{2}$ to heated phosphoric acid at $150{ }^{\circ} \mathrm{C}$, followed by precipitation of $\mathrm{LaPO}_{4}$ within 30 minutes. ${ }^{9}$ With this method, at least $4 \%$ Sr-doped $\mathrm{LaPO}_{4}$ was

45 obtained. These results suggest that the solubility of Sr would be higher at lower temperatures. Besides temperature, water vapor pressure may also affect the solubility of $\mathrm{Sr}$. When $\mathrm{Sr}$ is doped into $\mathrm{LaPO}_{4}$, a certain amount of water is also introduced into $\mathrm{LaPO}_{4}$ as represented by the following 50 expression:

$$
\begin{aligned}
& (1-x) \mathrm{LaPO}_{4}+(x / 2) \mathrm{Sr}_{2} \mathrm{P}_{2} \mathrm{O}_{7}+(y / 2) \mathrm{H}_{2} \mathrm{O} \\
& \rightarrow \mathrm{La}_{1-x} \mathrm{Sr}_{x} \mathrm{H}_{y} \mathrm{PO}_{4-(x / 2)+(y / 2)} .
\end{aligned}
$$

Therefore, Sr-doped $\mathrm{LaPO}_{4}\left(\mathrm{La}_{1-x} \mathrm{Sr}_{x} \mathrm{H}_{y} \mathrm{PO}_{4-(x / 2)+(y / 2)}\right)$ would be stabilized with higher water vapor pressure. However, the relationship between the solubility of $\mathrm{Sr}$ and these parameters 55 has not been clarified yet.

When the above synthesis methods are used, powder samples are generally obtained. For use as electrolytes, they need to be sintered at over $1000{ }^{\circ} \mathrm{C}$ for densification. This heat treatment is expected to limit the solubility of $\mathrm{Sr}$ to 60 approximately $2 \%$. ${ }^{7}$ Therefore, to synthesize highly Sr-doped $\mathrm{LaPO}_{4}$, avoiding high temperature heat treatments in syntheses would also be important.

Synthesis of single crystals of rare earth ultraphosphates $\left(\mathrm{REP}_{5} \mathrm{O}_{14}\right.$, RE: rare earth elements) in phosphoric acid 65 solutions has been the subject of intensive investigations since the 1970s, for the purpose of using them as laser materials. 10,11 In the series of these researches, Chudinova et al. investigated the $\mathrm{La}_{2} \mathrm{O}_{3}-\mathrm{P}_{2} \mathrm{O}_{5}-\mathrm{H}_{2} \mathrm{O}$ system and reported that $\mathrm{LaPO}_{4}$ precipitated in phosphoric acid solutions at below $70160{ }^{\circ} \mathrm{C}$. ${ }^{12}$ Although there is no detailed information on the precipitation behavior of $\mathrm{LaPO}_{4}$, it is possible to obtain Srdoped $\mathrm{LaPO}_{4}$ with sufficiently large size and density for use as electrolytes directly.

Therefore, synthesis of $\mathrm{LaPO}_{4}$ in homogeneous phosphoric 75 acid solutions was performed in this research. The conditions (temperature and water vapor pressure) where $\mathrm{LaPO}_{4}$ can be precipitated in phosphoric acid solutions were investigated. The morphology of precipitates was also observed. Then, the condition dependence of the Sr doping level was analyzed to 80 reveal the optimum condition for obtaining highly Sr-doped $\mathrm{LaPO}_{4}$. The effectiveness of $\mathrm{Sr}$ doping was verified by observing unit cell volume changes by doping and the evaporation of $\mathrm{H}_{2} \mathrm{O}$ which had been incorporated into $\mathrm{LaPO}_{4}$ 
during the synthesis. Finally, the stability of Sr-doped $\mathrm{LaPO}_{4}$ at high temperatures was investigated.

\section{Experimental}

\subsection{Synthesis}

${ }_{5}$ Undoped and Sr-doped $\mathrm{LaPO}_{4}$ were synthesized by precipitation in homogeneous phosphoric acid solutions containing $\mathrm{La}_{2} \mathrm{O}_{3}$ and $\mathrm{SrCO}_{3} . \mathrm{La}_{2} \mathrm{O}_{3}$ (99.99\%, Nacalai Tesque), $\mathrm{SrCO}_{3}$ (99.99\%, Wako Pure Chemical Industries), and $\mathrm{H}_{3} \mathrm{PO}_{4}$ (85\%, Nacalai Tesque) were mixed in a perfluoroalkoxy 10 (PFA) beaker and held at $190{ }^{\circ} \mathrm{C}$ in a furnace for several days to obtain a transparent solution. Then temperature and water vapor pressure were changed and held for a predetermined period of time to precipitate $\mathrm{LaPO}_{4}$. The temperature was set between $120^{\circ} \mathrm{C}$ and $250{ }^{\circ} \mathrm{C}$, and the water vapor pressure was 15 set to approximately 0.01 atm (atmospheric conditions) or 1 atm (humidified conditions). Synthesis parameters are summarized in Table 1 and Table 2.

For humidification, the apparatus shown in Fig. 1 was used. The whole apparatus was placed in a furnace kept at a 20 constant temperature. A beaker was put on a stainless steel floor plate and covered with a stainless steel box with a capacity of $2.64 \mathrm{~L}$. A 4-m-long spiral tube was attached to a side wall of the box. Liquid water was fed to the box through the spiral tube so that it evaporated before reaching the box.

25 The liquid water feed rate was $0.1 \mathrm{~mL} / \mathrm{min}$, which was equivalent to $0.18 \mathrm{~L}-\mathrm{H}_{2} \mathrm{O}(\mathrm{g}) / \mathrm{min}$ at $120{ }^{\circ} \mathrm{C}$ and $0.24 \mathrm{~L}$ $\mathrm{H}_{2} \mathrm{O}(\mathrm{g}) / \mathrm{min}$ at $250^{\circ} \mathrm{C}$. The apparatus was not sealed tightly so that the inner gas was able to flow out through the narrow gap between the box and the floor plate when the inner pressure 30 exceeded $1 \mathrm{~atm}$. Therefore, the water vapor pressure inside the box was expected to be $1 \mathrm{~atm}$.

After the predetermined precipitation period, the beaker was cooled down to room temperature. In general, there were precipitates on the bottom of the beaker and the transparent 35 solution above them. The solution was collected for the chemical analysis. The precipitates were washed well with hot water $\left(\sim 90^{\circ} \mathrm{C}\right)$.

\subsection{Characterization}

Phase identification was carried out via X-ray powder 40 diffraction (XRD) analysis on PANalytical X'Pert-Pro MPD using $\mathrm{Cu} \mathrm{K} \alpha$ radiation at room temperature. The unit cell volume of samples was evaluated by the Rietveld method using X'Pert HighScore Plus (Version 2.2c) software. The morphology of precipitates was investigated using KEYENCE 45 VE-7800 scanning electron microscopy (SEM). Chemical analysis of solutions and precipitates was performed by inductively coupled plasma atomic emission spectrometry (ICP-AES) on Seiko Instruments SPS4000.

The amount of $\mathrm{H}_{2} \mathrm{O}$ evaporated from samples was so determined by the Karl Fischer titration method. The samples were dried in advance at $600{ }^{\circ} \mathrm{C}$ for $50 \mathrm{~h}$ in the air $\left(p \mathrm{H}_{2} \mathrm{O} \sim\right.$ $0.01 \mathrm{~atm}$ ) to eliminate residual water and phosphoric acid on the surface of samples. The protons responsible for the proton conduction were still expected to remain in the samples, 55 judging from the reported $\mathrm{pH}_{2} \mathrm{O}$ dependence of the conductivity at $600{ }^{\circ} \mathrm{C}$. ${ }^{6}$ Then each sample was held at $800{ }^{\circ} \mathrm{C}$ under dry nitrogen flow $(200 \mathrm{~mL} / \mathrm{min})$ to be dehydrated. The nitrogen which contains the released $\mathrm{H}_{2} \mathrm{O}$ was transferred to the Karl Fischer moisture titrator to 60 determine the amount of $\mathrm{H}_{2} \mathrm{O}$ evaporated from the sample. For this, Kyoto Electronics Manufacturing MKC-510N (KarlFischer moisture titrator) and ADP-512S (evaporator) were utilized.

Table 1 Initial compositions of solutions for the synthesis of $\mathrm{LaPO}_{4}$.

\begin{tabular}{|c|c|c|c|}
\hline \multirow[b]{2}{*}{ Abbrev. } & \multirow[b]{2}{*}{ Starting materials } & \multicolumn{2}{|c|}{ Initial composition } \\
\hline & & $\begin{array}{l}\text { Molar ratio } \\
\text { La : Sr : P }\end{array}$ & $\left(\frac{\mathrm{Sr}}{\mathrm{La}+\mathrm{Sr}}\right)(\mathrm{mol} \%)$ \\
\hline Sr0 & & $1.00: 0.00: 15$ & 0 \\
\hline Sr4 & $\mathrm{La}_{2} \mathrm{O}_{3}, \mathrm{SrCO}_{3}, \mathrm{H}_{3} \mathrm{PO}_{4}$ & $0.96: 0.04: 15$ & 4 \\
\hline Sr8 & & $0.92: 0.08: 15$ & 8 \\
\hline
\end{tabular}

65

Table 2 Dissolution and precipitation conditions for the synthesis of $\mathrm{LaPO}_{4}$.

\begin{tabular}{|c|c|c|c|c|}
\hline \multirow{2}{*}{ Abbrev. } & \multicolumn{2}{|c|}{ Dissolution } & \multicolumn{2}{|c|}{ Precipitation } \\
\hline & Temp. $\left({ }^{\circ} \mathrm{C}\right)$ & $p \mathrm{H}_{2} \mathrm{O}$ (atm) & Temp. $\left({ }^{\circ} \mathrm{C}\right)$ & $\overline{p \mathrm{H}_{2} \mathrm{O}(\mathrm{atm})}$ \\
\hline A230 & \multirow{6}{*}{190} & \multirow{6}{*}{$\sim 0.01$} & 230 & $\sim 0.01$ \\
\hline A140 & & & 140 & $\sim 0.01$ \\
\hline A120 & & & 120 & $\sim 0.01$ \\
\hline H250 & & & 230 & $\sim 1$ \\
\hline H140 & & & 140 & $\sim 1$ \\
\hline H120 & & & 120 & $\sim 1$ \\
\hline
\end{tabular}

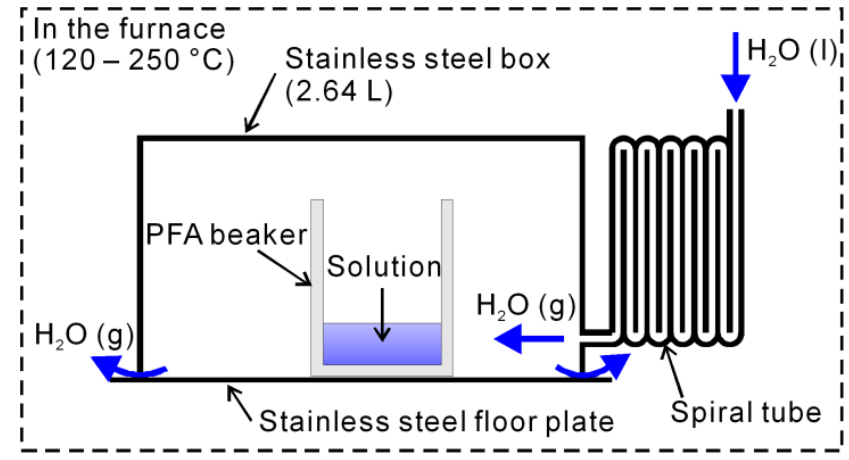

70 Fig. 1 Schematic illustration of the apparatus used for humidification during the precipitation of $\mathrm{LaPO}_{4}$.

\section{Results and discussion}

\subsection{Precipitation condition and crystal morphology of $\mathrm{LaPO}_{4}$ and $\mathrm{LaP}_{3} \mathrm{O}_{9}$}

75 The precipitation condition of $\mathrm{LaPO}_{4}$ was investigated using solutions with the composition Sr0. Experiments were performed under both atmospheric (A230, A140) and humidified (H250, H140) conditions. Fig. 2 shows the X-ray diffraction patterns of the precipitates obtained under each 80 condition. Under the atmospheric conditions, monazite-type $\mathrm{LaPO}_{4}$ was obtained at $140{ }^{\circ} \mathrm{C}$ while $\mathrm{LaP}_{3} \mathrm{O}_{9}$ was obtained at $230^{\circ} \mathrm{C}$. This is consistent with the results reported by 


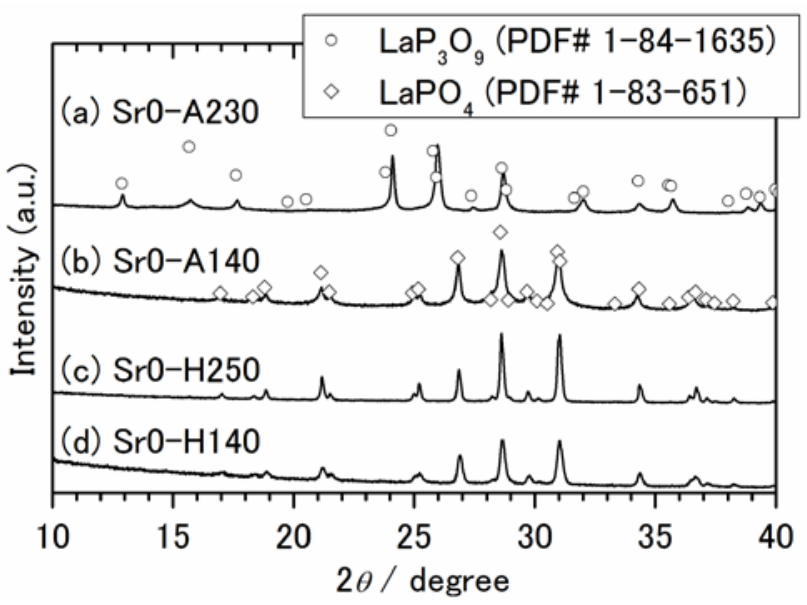

Fig. $2 \mathrm{X}$-ray powder diffraction patterns of undoped $\mathrm{LaPO}_{4}$ and $\mathrm{LaP}_{3} \mathrm{O}_{9}$ precipitates obtained under the conditions (a) A230, (b) A140, (c) H250, and (d) H140.

${ }_{5}$ Chudinova et al. ${ }^{12}$ Under the humidified conditions, monazite-type $\mathrm{LaPO}_{4}$ was obtained both at $250{ }^{\circ} \mathrm{C}$ and $140{ }^{\circ} \mathrm{C}$. With these results, the precipitation region of $\mathrm{LaPO}_{4}$ was drawn on the temperature $-p \mathrm{H}_{2} \mathrm{O}$ plane (Fig. 3). As indicated in the figure, increasing $p \mathrm{H}_{2} \mathrm{O}$ from 0.01 to 1 atm extends the 10 precipitation region of $\mathrm{LaPO}_{4}$ toward higher temperatures by nearly $100{ }^{\circ} \mathrm{C}$. At $1 \mathrm{~atm} \mathrm{H}_{2} \mathrm{O}, \mathrm{LaPO}_{4}$ can be obtained even at $250{ }^{\circ} \mathrm{C}$, where $\mathrm{LaP}_{3} \mathrm{O}_{9}$ will be obtained at lower $p \mathrm{H}_{2} \mathrm{O}$ such as $0.2 \mathrm{~atm}$. The analogous phenomenon for $\mathrm{LaP}_{3} \mathrm{O}_{9}$ and $\mathrm{LaP}_{5} \mathrm{O}_{14}$ was reported in detail by Balagina et al. ${ }^{13}$

15 Fig. 4 shows SEM images of undoped $\mathrm{LaPO}_{4}$ and $\mathrm{LaP}_{3} \mathrm{O}_{9}$ precipitates. Under the conditions A140 and $\mathrm{H} 140, \mathrm{LaPO}_{4}$ precipitates were rice-shaped particles with a size range of $500 \mathrm{~nm}-1 \mu \mathrm{m}$. In contrast, under $\mathrm{H} 250$ condition, the $\mathrm{LaPO}_{4}$ precipitates were dense aggregates of well-shaped crystals up 20 to $200 \mu \mathrm{m}$. Thus, the precipitation temperature had a marked effect on the crystal growth of $\mathrm{LaPO}_{4}$. Higher precipitation temperatures, in combination with humidification, may enable direct syntheses of dense $\mathrm{LaPO}_{4}$ electrolytes in phosphoric acid solutions.



Fig. 4 SEM images of undoped $\mathrm{LaPO}_{4}$ and $\mathrm{LaP}_{3} \mathrm{O}_{9}$ precipitates obtained under the conditions (a) A230, (b) A140, (c) H250, and (d) H140.

\subsection{Optimum condition for obtaining highly Sr-doped $\mathrm{LaPO}_{4}$}

30 Attempts to synthesize Sr-doped $\mathrm{LaPO}_{4}$ were carried out using solutions with the compositions $\mathrm{Sr} 4$ and Sr8. Experiments were performed in the precipitation region of $\mathrm{LaPO}_{4}$ (see Fig. 3) under both atmospheric (A120) and humidified (H250, H120) conditions. The precipitation period was varied to 35 observe changes in the composition of precipitates and solutions with time. In each condition, single phase $\mathrm{LaPO}_{4}$ was precipitated, as confirmed by X-ray diffraction.

Fig. 5 shows the change in the composition of the solutions with time measured by ICP. The concentrations of La and $\mathrm{Sr}$ 40 decreased with time. In particular, under H120 condition, the concentrations decreased rapidly by $2-3$ orders. This indicates that the solubility of $\mathrm{LaPO}_{4}$ in phosphoric acid solutions is especially low under $\mathrm{H} 120$ condition, or the driving force for the precipitation is strong under that 45 condition. This result corresponds well to the fact that $\mathrm{H} 120$ condition is quite deep in the precipitation region of $\mathrm{LaPO}_{4}$ in Fig. 3. Under A120 condition, the changes in the

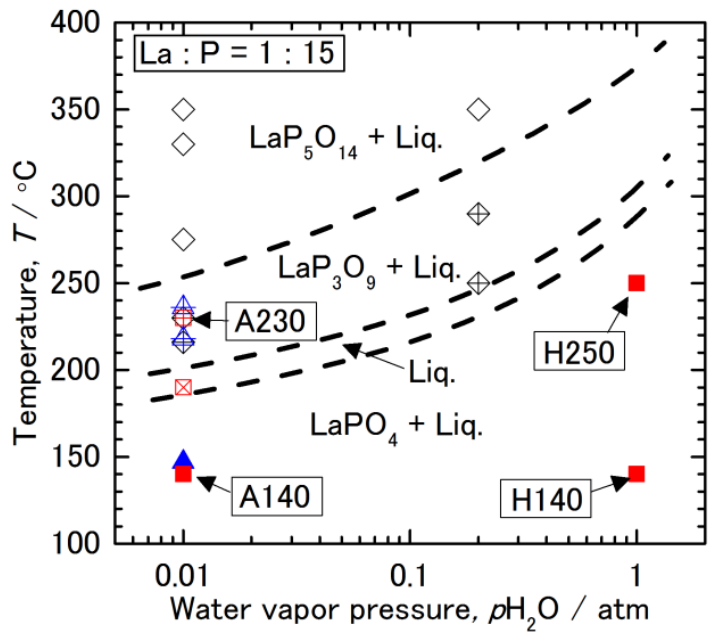

\begin{tabular}{lccc}
\hline $\begin{array}{l}\text { Solid } \\
\text { phase }\end{array}$ & $\begin{array}{c}\text { This } \\
\text { work }\end{array}$ & $\begin{array}{c}\text { Ref. } \\
12\end{array}$ & $\begin{array}{c}\text { Ref. } \\
13\end{array}$ \\
\hline $\mathrm{LaP}_{5} \mathrm{O}_{14}$ & & & $\diamond$ \\
$\mathrm{LaP}_{3} \mathrm{O}_{9}$ & $\boxplus$ & 4 & $\bullet$ \\
$\mathrm{LaPO}_{4}$ & $\square$ & $\boldsymbol{\Delta}$ & \\
None & $\otimes$ & & \\
\hline
\end{tabular}

50 Fig. 3 Phase stability diagram of the $\mathrm{La}_{2} \mathrm{O}_{3}-\mathrm{P}_{2} \mathrm{O}_{5}-\mathrm{H}_{2} \mathrm{O}$ system with a constant La/P ratio ( $\mathrm{La}: \mathrm{P}=1$ : 15). In addition to the results obtained in this study, previous results reported by Chudinova et al. ${ }^{12}$ and Balagina et al. ${ }^{13}$ are also shown. 


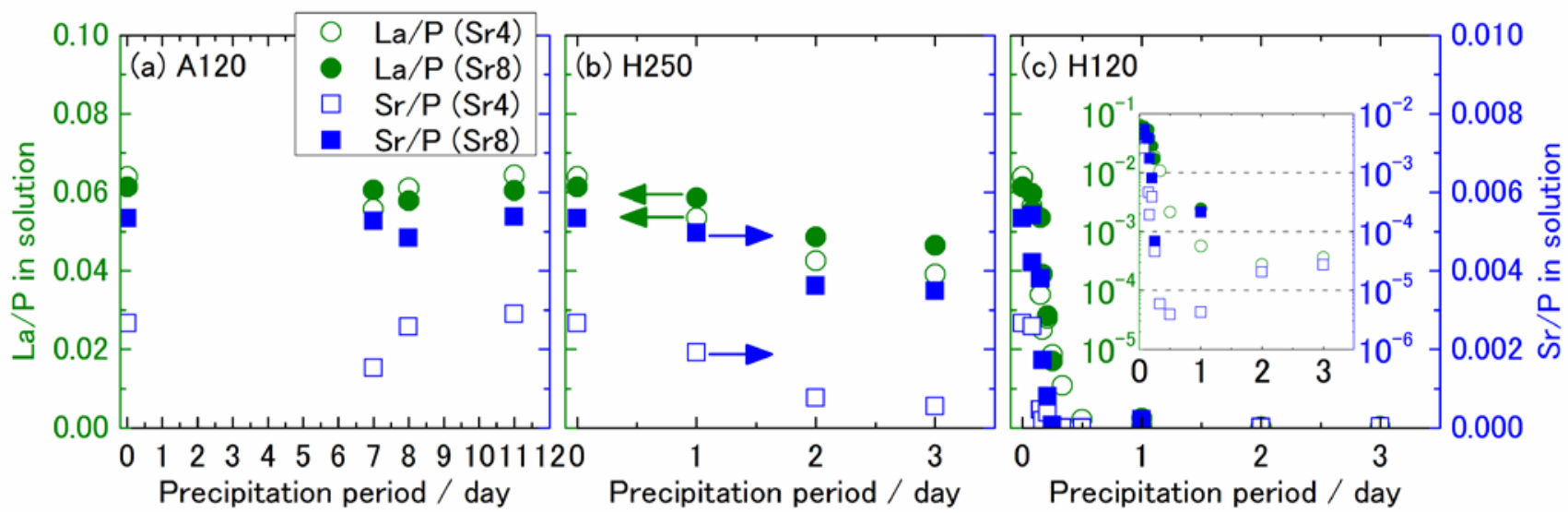

Fig. 5 Change in composition of solutions with time under the conditions (a) A120, (b) H250, and (c) H120. Inset in (c) is a logarithmic plot.

concentrations of La and Sr fluctuated. This is likely due to the fluctuation of water vapor pressure in the atmosphere.

5 For better understanding of the precipitation behavior, these concentration values were converted into "precipitation ratios." We defined the precipitation ratio of element $\mathrm{M}, X_{\mathrm{M}}$, by the following formula:

$$
X_{\mathrm{M}} \equiv \frac{n_{\mathrm{M} . \text { prec }}}{n_{\mathrm{M}, \text { init }}} \times 100(\%),
$$

10 where $n_{\mathrm{M}}$, prec and $n_{\mathrm{M}}$, init are the quantities of $\mathrm{M}$ in the precipitate and initial solution, respectively. For example, $X_{\mathrm{La}}$ will be $100 \%$ when all La in the initial solution precipitates as $\mathrm{LaPO}_{4}$. Fig. 6 shows the changes in $X_{\mathrm{La}}$ and $X_{\mathrm{Sr}} \cdot X_{\mathrm{Sr}}$ was greater than $X_{\mathrm{La}}$ in the early stages of the precipitation 15 regardless of the initial composition of the solution. This suggests the formation of Sr-richer $\mathrm{LaPO}_{4}$ than the initial solutions.

The Sr doping levels in the $\mathrm{LaPO}_{4}$ precipitates analyzed by ICP, Fig. 7, showed a strong dependence on $X_{\mathrm{La}}$. In good

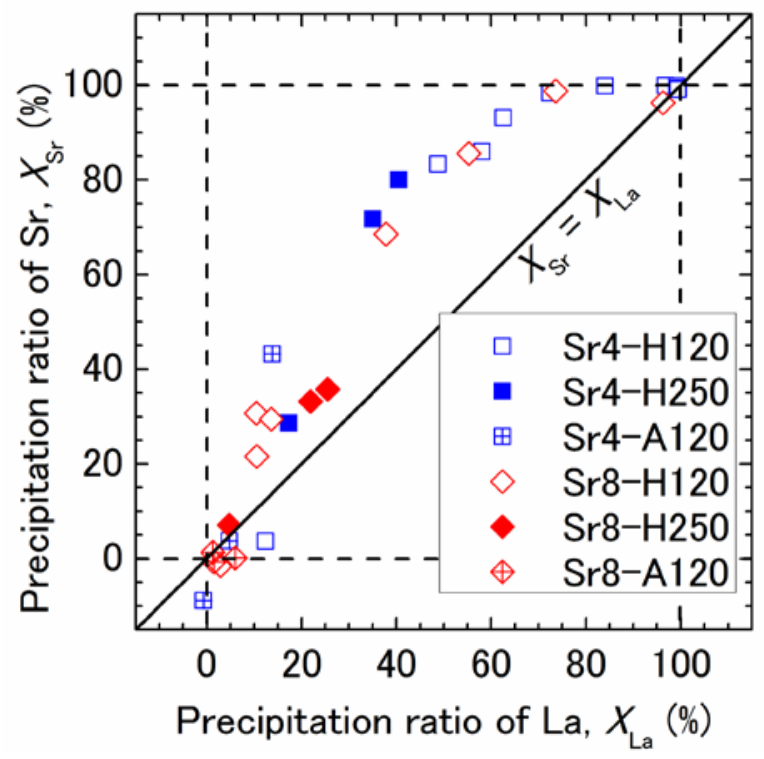

Fig. 6 Change in the precipitation ratios of $\mathrm{La}$ and $\mathrm{Sr}$ observed along with the progression of the precipitation of $\mathrm{LaPO}_{4}$. agreement with the precipitation ratio changes described above (Fig. 6), the Sr doping levels in the precipitates were ${ }_{25}$ higher in the low $X_{\mathrm{La}}$ region, reaching $20 \mathrm{~mol} \%$ at maximum. This value is one order of magnitude higher than the reported solubilities of $\mathrm{Sr}$ in $\mathrm{LaPO}_{4}{ }^{7,8}$ The precipitation temperature and $\mathrm{pH}_{2} \mathrm{O}$ did not seem to have a significant effect on this trend, although they affect the attainable precipitation ratio 30 limited by thermodynamics, and the Sr doping level accordingly. Thus, it can be concluded that the precipitation method in homogeneous phosphoric acid solutions serves as the most effective synthesis route to date for highly Sr-doped $\mathrm{LaPO}_{4}$.

\section{3.3. Effectiveness of Sr doping}

To examine whether $\mathrm{Sr}$ was doped correctly and $\mathrm{H}_{2} \mathrm{O}$ was incorporated in the bulk as desired, the following two methods were used: (1) The amount of $\mathrm{H}_{2} \mathrm{O}$ evaporated from samples at $800{ }^{\circ} \mathrm{C}$ in dry $\mathrm{N}_{2}$ was measured by the Karl Fischer titration 40 method. (2) The unit cell volume of samples was evaluated before and after the $\mathrm{H}_{2} \mathrm{O}$ evaporation measurement using

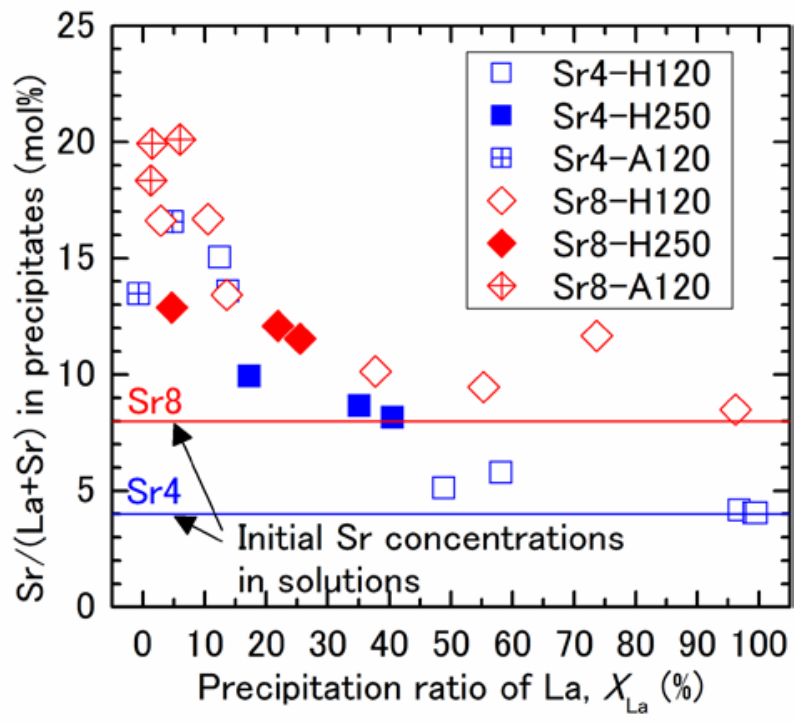

Fig. 7 Dependence of the Sr doping level in $\mathrm{LaPO}_{4}$ on the precipitation ratio of La. 




Sr doping level (mol\%)

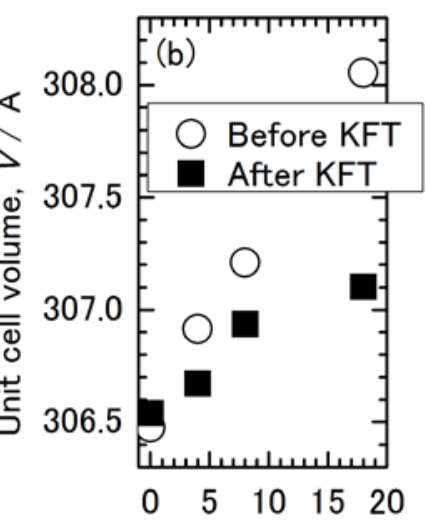

Sr doping level ( $\mathrm{mol} \%)$
Fig. 8 (a) $\mathrm{H}_{2} \mathrm{O}$ evaporation from Sr-doped $\mathrm{LaPO}_{4}$ under $\mathrm{N}_{2}$ at $800{ }^{\circ} \mathrm{C}$ as measured by the Karl Fischer titration (KFT) method. The samples were held in the air at $600{ }^{\circ} \mathrm{C}$ for $50 \mathrm{~h}$ beforehand. (b) Unit cell volume of Sr5 doped $\mathrm{LaPO}_{4}$ as determined by Rietveld analysis using powder X-ray diffraction patterns. The open circles $(O)$ represent the cell volume of samples before the titration (just after held in the air at $600{ }^{\circ} \mathrm{C}$ for $50 \mathrm{~h}$ ). The filled squares (घ) represent the cell volume of samples after the titration.

10 powder X-ray diffraction patterns. Prior to these measurements, samples were dried at $600{ }^{\circ} \mathrm{C}$ in the air for 50 h.

Fig. 8 (a) represents the $\mathrm{H}_{2} \mathrm{O}$ evaporation from $\mathrm{LaPO}_{4}$ (expressed in percentage of the initial weight of each sample) 15 with different $\mathrm{Sr}$ doping levels (0, 4, 8 and $18 \mathrm{~mol} \%$ ). Although the plots are not linear, $\mathrm{H}_{2} \mathrm{O}$ evaporation monotonically increased with increasing the Sr doping level. This should indicate that $\mathrm{H}_{2} \mathrm{O}$ was incorporated in $\mathrm{LaPO}_{4}$ with $\mathrm{Sr}$ on the synthesis. Fig. 8 (b) shows the unit cell volume of 20 samples before and after the $\mathrm{H}_{2} \mathrm{O}$ evaporation measurement. In both cases, $\mathrm{LaPO}_{4}$ with higher Sr doping level had larger unit cell volume. This would indicate that Sr substituted for $\mathrm{La}$ in the monazite structure, since the ionic radius of $\mathrm{Sr}^{2+}$ in ninefold coordination $(1.31 \AA)$ is larger than that of $\mathrm{La}^{3+}(1.21$ ${ }_{25} \AA$ ). ${ }^{14}$ After the $\mathrm{H}_{2} \mathrm{O}$ evaporation measurement, the unit cell volume of Sr-doped $\mathrm{LaPO}_{4}$ significantly decreased while that of undoped $\mathrm{LaPO}_{4}$ remain unchanged. This would reflect the evaporation of $\mathrm{H}_{2} \mathrm{O}$ from the bulk Sr-doped $\mathrm{LaPO}_{4}$. In Fig. 8 (a) the small $\mathrm{H}_{2} \mathrm{O}$ evaporation was observed even from 30 undoped $\mathrm{LaPO}_{4}$, but it could be due to some residual water on the surface or grain boundaries of the sample.

These results suggest that Sr successfully substituted for La and $\mathrm{H}_{2} \mathrm{O}$ was certainly incorporated in the bulk as desired.

\subsection{High temperature stability of Sr-doped $\mathrm{LaPO}_{4}$}

35 To evaluate the stability of highly Sr-doped $\mathrm{LaPO}_{4}, 13.4 \%$ Sr-doped $\mathrm{LaPO}_{4}$ and $20.1 \%$ Sr-doped $\mathrm{LaPO}_{4}$ synthesized in phosphoric acid solutions were heat treated at higher temperatures. The samples were first held at $600{ }^{\circ} \mathrm{C}$ for $80 \mathrm{~h}$ in the atmosphere, then the $13.4 \%$ doped sample was 40 additionally held at $1200{ }^{\circ} \mathrm{C}$ for 5 h. Fig. 9 shows the X-ray diffraction patterns obtained after each heat treatment. While no secondary phase was detected after the first heat treatment at $600{ }^{\circ} \mathrm{C}$, the presence of secondary phases, $\mathrm{Sr}_{2} \mathrm{P}_{2} \mathrm{O}_{7}$ and $\mathrm{Sr}_{3} \mathrm{La}\left(\mathrm{PO}_{4}\right)_{3}$, was clearly detected after the second heat 45 treatment at $1200{ }^{\circ} \mathrm{C}$. Amezawa et al. reported $\mathrm{Sr}_{2} \mathrm{P}_{2} \mathrm{O}_{7}$ as the secondary phase at $1200{ }^{\circ} \mathrm{C}$ and $\mathrm{Sr}_{3} \mathrm{La}\left(\mathrm{PO}_{4}\right)_{3}$ at above $1350{ }^{\circ} \mathrm{C}$. ${ }^{6}$ Tyholdt et al. also reported both as the secondary phases at $1450{ }^{\circ} \mathrm{C}$. ${ }^{8}$ The detection of both $\mathrm{Sr}_{2} \mathrm{P}_{2} \mathrm{O}_{7}$ and $\mathrm{Sr}_{3} \mathrm{La}\left(\mathrm{PO}_{4}\right)_{3}$ in the present study is somewhat incompatible with the previous 50 study by Amezawa but it could be due to some kinetic reason. The present results indicate that the solubility of $\mathrm{Sr}$ in $\mathrm{LaPO}_{4}$ would be sufficiently high (at least $20.1 \%$ ) at $600{ }^{\circ} \mathrm{C}$, which is in the operating temperature range for the electrolyte. However, the solubility of $\mathrm{Sr}$ is considerably lower than

(b) $20.1 \% \mathrm{Sr}$-doped $\mathrm{LaPO}_{4}$

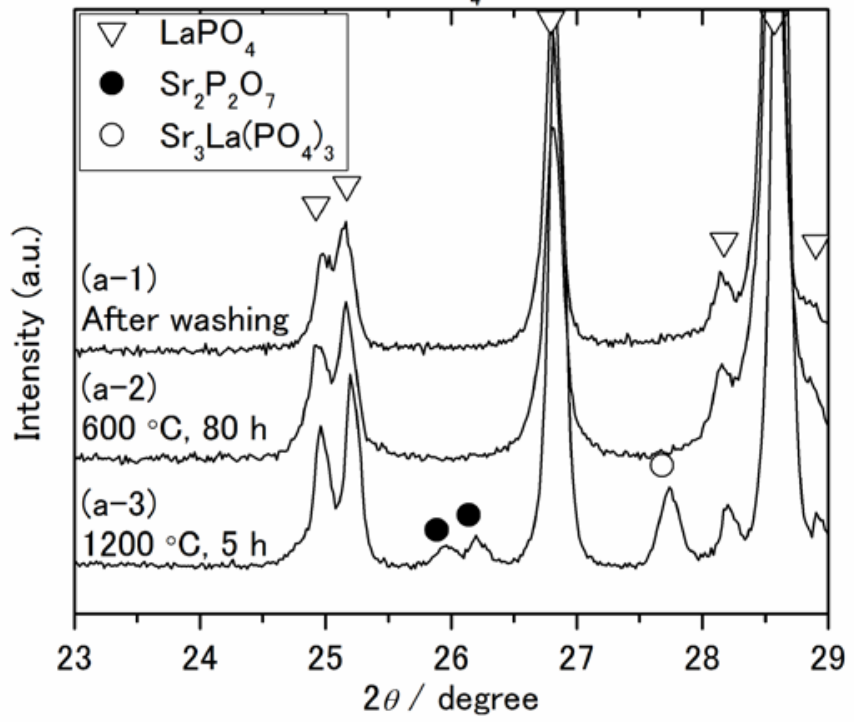

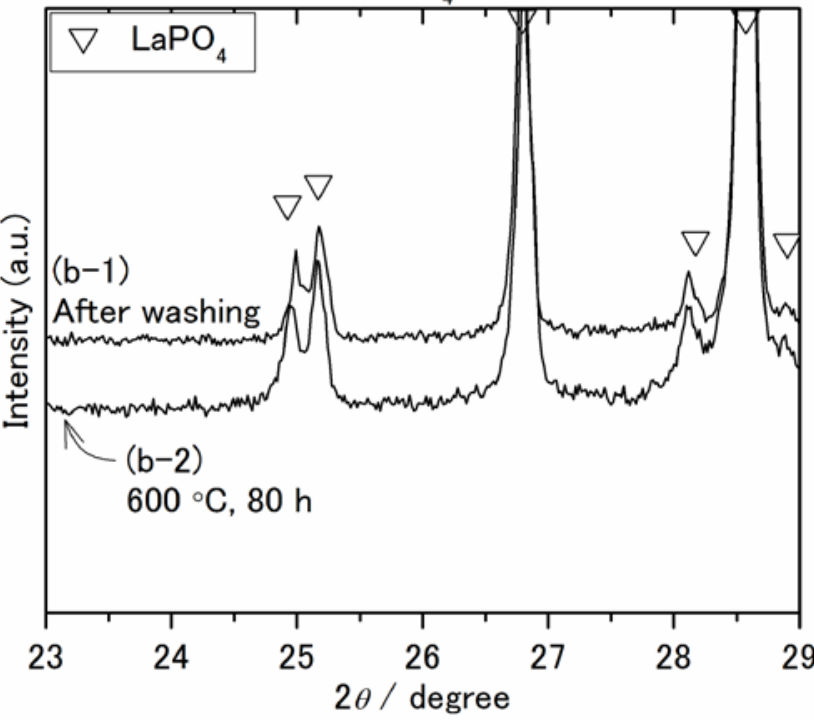

Fig. 9 X-ray diffraction patterns of (a) 13.4\% Sr-doped $\mathrm{LaPO}_{4}$ and (b) 20.1\% Sr-doped $\mathrm{LaPO}_{4}$. They were collected (a-1)(b-1) just after washing, (a-2)(b2) after the first heat treatment at $600{ }^{\circ} \mathrm{C}$ for $80 \mathrm{~h}$ and (a-3) after the second heat treatment at $1200{ }^{\circ} \mathrm{C}$ for 5 h. Peaks marked with $\nabla$, $\boldsymbol{0}$, and $\bigcirc$ are attributed to $\mathrm{LaPO}_{4}\left(\mathrm{PDF} \# 1\right.$ 1-83-651), $\mathrm{Sr}_{2} \mathrm{P}_{2} \mathrm{O}_{7}$ (PDF\#0-24-1011), and $\mathrm{Sr}_{3} \mathrm{La}\left(\mathrm{PO}_{4}\right)_{3}$ (PDF\# 0-29-1306), respectively. 
$13.4 \%$ at $1200{ }^{\circ} \mathrm{C}$, which is a typical sintering temperature for this material. Therefore, a new synthesis process of $\mathrm{LaPO}_{4}$ electrolytes based on precipitation in homogeneous phosphoric acid solutions, which enables synthesizing dense ${ }_{5} \mathrm{LaPO}_{4}$ electrolytes without sintering, should have a great advantage. The stability of Sr-doped $\mathrm{LaPO}_{4}$ for longer periods will be the subject of future studies.

\section{Conclusions}

In this study, we investigated the precipitation condition of ${ }_{10} \mathrm{LaPO}_{4}$ in phosphoric acid solutions and the morphology of the precipitates. We also studied the optimum condition for obtaining highly Sr-doped $\mathrm{LaPO}_{4}$. Then we examined the effectiveness of doping. Finally we evaluated the stability of Sr-doped $\mathrm{LaPO}_{4}$ at high temperatures. The findings can be 15 summarized as follows:

(1) Increasing $\mathrm{pH}_{2} \mathrm{O}$ from 0.01 atm to 1 atm extends the precipitation region of $\mathrm{LaPO}_{4}$ in phosphoric acid solutions toward higher temperatures by nearly $100{ }^{\circ} \mathrm{C}$. It is possible to obtain aggregated $\mathrm{LaPO}_{4}$ crystals up to $200 \mu \mathrm{m}$

20 under such conditions (e.g. $\mathrm{T}=250{ }^{\circ} \mathrm{C}$ and $\left.\mathrm{pH}_{2} \mathrm{O}=1 \mathrm{~atm}\right)$. This may facilitate the direct synthesis of dense $\mathrm{LaPO}_{4}$ electrolytes in phosphoric acid solutions.

(2) The Sr doping level in $\mathrm{LaPO}_{4}$ shows a strong dependence on the precipitation ratio of La, $X_{\mathrm{La}}$. The Sr doping level is

25 higher in the low $X_{\mathrm{La}}$ region, reaching $20 \%$ at maximum. This value is one order of magnitude higher than the previously reported solubilities of $\mathrm{Sr}$ in $\mathrm{LaPO}_{4}$.

(3) $\mathrm{Sr}$ partially substitutes for La in monazite-type $\mathrm{LaPO}_{4}$ when synthesized in phosphoric acid solutions, as well as by solid state reaction as reported in literature. On synthesis, $\mathrm{H}_{2} \mathrm{O}$ is certainly incorporated in the bulk by $\mathrm{Sr}$ doping.

(4) The solubility of $\mathrm{Sr}$ in $\mathrm{LaPO}_{4}$ would be sufficiently high (at least $20.1 \%$ ) even at $600{ }^{\circ} \mathrm{C}$, which is in the operating

35 temperature range for the electrolyte. However, it becomes considerably lower than $13.4 \%$ at $1200{ }^{\circ} \mathrm{C}$.

\section{Acknowledgments}

This work was financially supported by MEXT Elements Science and Technology Project and a Grant-in-Aid for JSPS 40 Fellows. The authors would like to thank Mr. Takahito Nakajima at Kyoto University for his experimental assistance.

\section{Notes and references}

${ }^{a}$ Department of Materials Science and Engineering, Kyoto

University,Yoshida Honmachi, Sakyo-ku, Kyoto, 606-8501, Japan. Fax:

45 +81-75-753-5284, Tel: +81-75-753-5445, E-mail:

materials_process@aqua.mtl.kyoto-u.ac.jp

1 T. Norby and N. Christiansen, Solid State Ionics, 1995, 77, 240-243.

2 K. Amezawa, S. Kjelstrup, T. Norby, and Y. Ito, J. Electrochem. Soc., $50 \quad$ 1998, 145(10), 3313-3319.

3 S. Gallini, M. Hänsel, T. Norby, M. T. Colomer, and J. R. Jurado, Solid State Ionics, 2003, 162-163, 167-173.

4 G. Harley, R. Yu, and L. C. D. Jonghe, Solid State Ionics, 2007, 178, 769-773.

555 K. Amezawa, Y. Tomii, and N. Yamamoto, Solid State Ionics, 2005, 176, 135-141.
6 K. Amezawa, H. Maekawa, Y. Tomii, and N. Yamamoto, Solid State Ionics, 2001, 145, 233-240.

7 K. Amezawa, Y. Tomii, and N. Yamamoto, Solid State Ionics, 2005, $60 \quad$ 176, 143-148.

8 F. Tyholdt, J. A. Horst, S. Jørgensen, T. Østvold, and T. Norby, Surf. Interface Anal., 2000, 30, 95-97.

9 M. T. Schatzmann, M. L. Mecartney, and P. E. D. Morgan, J. Mater. Chem., 2009, 19, 5720-5722.

6510 H. G. Danielmeyer, J. P. Jeser, E. Schönherr, and W. Stetter, J. Cryst. Growth, 1974, 22, 298-302.

11 K. Byrappa, Prog. Cryst. Growth Charact., 1986, 13, 163-196.

12 N. N. Chudinova, L. P. Shklover, and G. M. Balagina, Inorg. Mater., 1975, 11, 590-593.

7013 G. M. Balagina, N. N. Chudinova, and E. V. Murashova, Russ. J. Inorg. Chem., 2004, 49, 614-616.

14 R. D. Shannon, Acta Crysta., 1976, A32, 751-767. 